Article

\title{
Folklore in Antiquity
}

\author{
Galit Hasan-Rokem ${ }^{1, *}$ and Haim Weiss ${ }^{2}$
}

1 Department of Hebrew Literature and Graduate Program in the Study of Folklore and Folk Culture, Hebrew University of Jerusalem, Jerusalem 91905, Israel

2 Department of Hebrew Literature, Ben-Gurion University of the Negev, Beer-Sheva 8410501, Israel; weissh@bgu.ac.il

* Correspondence: hasanrokem@gmail.com

Received: 29 March 2018; Accepted: 8 May 2018; Published: 16 May 2018

\begin{abstract}
Folklore exists in all human groups, small and big. Since early modernity, scholars have provided various definitions of the phenomenon, but earlier texts may also reveal awareness and reflection on the specific character folklore. In this short article, we wish to explore and look into the various definitions and characterizations of folklore given by ancient writers from various times and cultures. We will try to draw a cultural map of awareness to the phenomenon of folklore in ancient Near-Eastern texts, Greco-Roman culture, the Hebrew Bible, Early Christianity and Rabbinic literature. The main questions we wish do deal with are where and if we can find explicit mention of folklore; which folk genres are dominant in ancient writings and what was the social context of ancient folklore? That is to say, whom those text integrated in social frameworks, enabling their users to gain power or to undermine existing cultural, theological and social structures.
\end{abstract}

Keywords: folk genres; ethnography; Greco-Roman Literature; Biblical Literature; Rabbinic Literature; Early Christianity; Ancient Near East; Jewish Folklore

\section{Introduction}

Folklore exists in all human groups, small and big. Since early modernity, scholars have provided various definitions of the phenomenon, ${ }^{1}$ but earlier texts may also reveal awareness and reflection on the specific character folklore. ${ }^{2}$ The modes and forms of folkloric creativity and communication change according to the conditions in which they take place. Visual and tangible forms of folklore depend, among other things, on the materials available, the climate, and the economic potential of their practitioners. Verbal forms of folklore are dependent on languages, as well as on the situational contexts and the social frameworks in which they are performed.

Today, studying the verbal folklore of the past is different from studying that of the present, lacking the contemporaneity of performers and those who study them. Until less than two centuries ago, the audial aspects of past folklore performances were not retainable, they could only be recorded as notations, such as notes. Even though technology has provided us with an array of devices to preserve both voices and images - still, as well as moving - much of the contextual information which gives folklore its meaning is lost in recordings. ${ }^{3}$ The study of ancient folklore is thus dependent on the written medium transmitting to us the genres of verbal folklore-although at least partly performed orally-as well as descriptions of other genres, such as rituals and games, and contextual knowledge of all kinds. Folklore, when interwoven into ancient texts, is particularly entangled with other modes of

\footnotetext{
Among many others: (Utley 1965; Ben-Amos 1971; Baumann and Briggs 2001; Bendix and Hasan-Rokem 2014).

(Patai et al. 1973; Graves and Patai 1983; Ziolkowski 2009; Hasan-Rokem 2009; Stein 2009).

(Fine 1984).
} 
culture; it is part of the repertoire of sophisticated written literatures in all periods, including antiquity. ${ }^{4}$ Ancient folklore has also reached our times through visual representation, such as sculptures, frescoes and mosaics.

Limitations of language and cultural proficiency dictate the choice of ancient cultures that we are able to review in this short essay. Thanks to our being scholars of late antique Rabbinic, and Talmudic-midrashic texts from folkloristic, ethnographic and literary perspectives, we have a certain competence vis a vis the folklores of the ancient Near East, including that in the Hebrew Bible, and those of the Classical Greek world, as well as the Hellenistic, Roman and early Christian cultures. Cultural contact of the Rabbinic world with the Indian and Persian worlds, and with pre-Moslem Middle Eastern, as well as early Moslem culture, allow us to refer to them too. We regret the omission of other antiquities, among them the Chinese, Japanese, African and the pre-Columbian American.

The identification of folklore in ancient texts depends on hermeneutical operations based on disciplinary models derived from the study of folklore in times closer to ours. Scholars of ancient folklore primarily use three methodological approaches to identify the objects of their study: explicit mention of folk, popular and oral sources, such as the Talmudic formula quoting proverbs "this is what the people say"; application of typological criteria developed in later materials, such as tale types; ${ }^{5}$ and the identification of genres based on phenomenological criteria. ${ }^{6}$

\section{In Their Own Words: Explicit Mention of Folk, Popular and Oral Sources}

The man commonly known as the Father of History was evidently endowed with this sobriquet before the fields of ethnography and folklore were fully recognized (as Herodotus could actually rightfully be called the Father of Ethnography and Folklore). Like the British enlighteners whom Bauman and Briggs set at the beginning of our disciplinary lineage, ${ }^{7}$ Aubrey and others, Herodotus too was analytically aware of an epistemological level of perception that contradicted scientific and other provable findings: ${ }^{8}$

The Thessalians themselves say that Poseidon made the channel through which the Peneios flows; and reasonably they report it thus, because whosoever believes that it is Poseidon who shakes the Earth and that the partings asunder produced by earthquakes are the work of this god, would say, if he saw this, that it was made by Poseidon; for the parting asunder of the mountains is the work of an earthquake, as is evident to me. ${ }^{9}$

Herodotus' rhetoric demonstrates a particularly early expression of a well-known approach, especially among cultural elites, i.e., that folklore belongs to "them". However, the ancients also observed the complex processes in which authors turned orally performed cultural modes into written texts, preserving them for posterity.

No less than Roman rhetorician Quintilian (c. 35-100 CE) has described, in some detail, the process of transposing ancient oral traditions in writing:

Therefore let pupils learn to paraphrase Aesop's fables, which follow closely upon the stories of nursery, in plain and unexcessive language; and thereafter to effect the same simplicity of style in writing. ${ }^{10}$

\footnotetext{
(Dundes 1965) proposes a preliminary discussion of this rich topic.

(Hansen 2017).

See also: (Ben-Amos 1967).

(Baumann and Briggs 2001), op. cit.

(Hartog 2001; Hartog 2009).

Herodotus, book 7 (129), tr. G. C. Macaulay, [1890]. Available online: http:/ /www.sacred-texts.com/cla/hh/hh7120.htm (accessed on 19 September 2017).

10 Quintilian, Institutio Oratoria I.9.2-3, ed. (Winterbottom 1970) I:58: (the Latin Text: Igitur Aesopi fabellas, quae fabulis nutricularum proxime succedunt, narrare sermone puro et nihil se supra modum extollente, deinde eandem gracilitatem stilo exigere condiscant). English translation: (Ziolkowski 2009, p. 102).
} 
Quintilian's gaze on folklore remains that of an outsider, hailing its simplicity, as would numerous writers after him. For Quintilian, Aesop's tales were cultural goods transmitted from the past. The earliest editions of the ancient Greek fabulist known to us stem from Quintilian's own period, attributed to Phaedrus (ca. 15 BCE-50 CE) and Babrius (2nd century CE), but since they were mentioned by earlier authors-e.g., Aristotle, Herodotus, Plutarch-Quintilian, provides a good example of the awareness of the ancients of the orally performed tales that were transmitted to them. The Aesopic tales are a prime example of the early distribution of folklore, since there are a fair number of parallels to them and, not only in the late antique Rabbinic Talmudic-Midrashic texts, ${ }^{11}$ but also in the major Indian tale compilations, such as the Panchatantra. ${ }^{12}$

Paul Veyne has, in his classic Did the Greeks Believe in their Myths?, made a strong point about the transmission of myth in the genre formations of folk tales and nursery rhymes, among others, in the private context of homes, as well as in oratories and philosophical discourses of the symposia. ${ }^{13}$ Others have added more detail: "tragedy, and comedy, epideictic oratory (and particularly in funeral speeches), in sophistic teaching, in festivals, and a variety of other contexts in which storytellers might perform" ${ }^{14}$ In another cultural context, and from a different hermeneutical perspective, Paul Ricoeur has highlighted the everyday life practices in which Jesus' parables are set. ${ }^{15}$ The Rabbis were certainly aware of oral modes of transmission, and even in their non-literary, legal, halakhic discourse, they saw it, for a long time, as the preferred mode of transmission. ${ }^{16}$ They also consciously recorded story-telling events. ${ }^{17}$ Scholarship has also revealed a particular awareness for folk narratives that may be epistemologically categorized as belonging to a world of yore and there, that existed in the imaginary world of the Rabbis of Babylonia in the fifth century, in the West, the Land of Israel, Roman Palestine, and a couple of centuries earlier. ${ }^{18}$

\section{Genres in Ancient Folklore}

The concept of genres has illuminated the field of folklore in its implicit articulations that we have suggested above, explicitly formulated in its early disciplinary formations. It became central since the systematic historical model of the Brothers Grimm ${ }^{19}$ at the early 19th century, and later in the long reigning "Folkloristic Method" of the geographical-historical or Finnish School. ${ }^{20}$ One basic genre distinction would be from early on between short and long forms. Among the short, or "minor" genres, proverbs are the most commonly used.

Since ancient times, humans have created proverbs and used them, as Samuel Noah Kramer has shown in his masterful History Begins in Sumer. ${ }^{21}$ The ancient Greeks-Aeschylus (Agamemnon), Aristophanes (Thesmophoriazusae, Birds), Apollodorus (Library, Epitome) among many others, quoted proverbs in their work often spelling out the genre label. ${ }^{22}$ Aristotle, who quotes ample proverbs in the Nichomacean Ethics, provided in his Rhetoric (3. 11 (14)) a characterization of the genre and a concrete example, obviously set in an oral context:

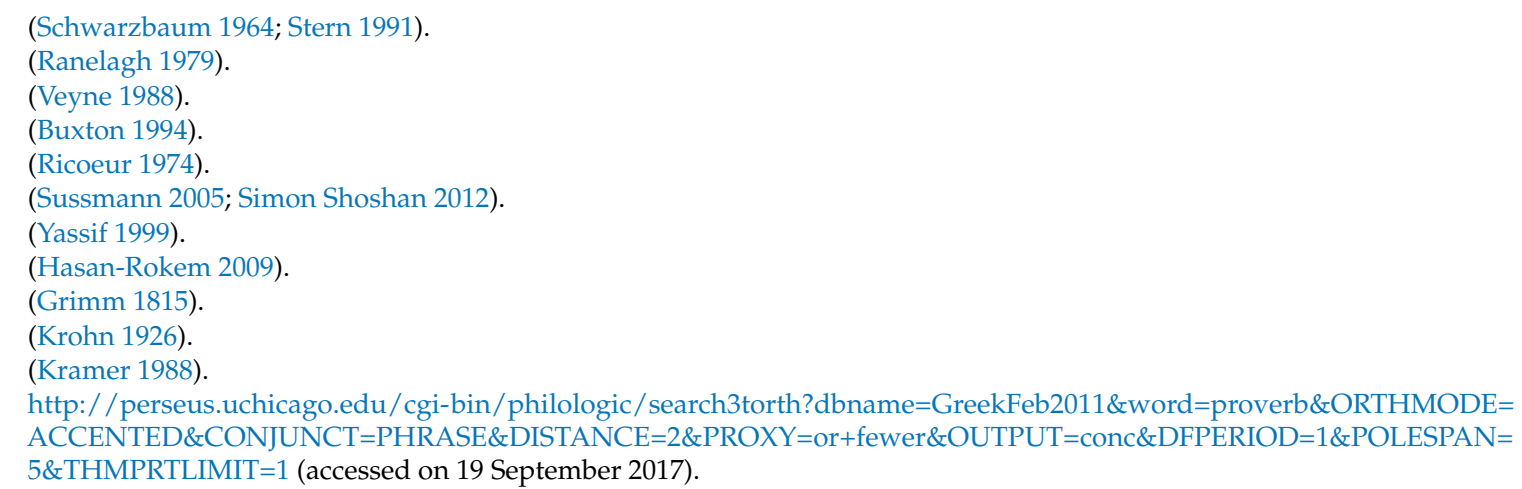


Proverbs also are metaphors from species to species. If a man, for instance, introduces into his house something from which he expects to benefit, but afterwards finds himself injured instead, it is as the Carpathian says of the hare; for both have experienced the same misfortunes. $^{23}$

The Hebrew Bible, as canonized by Jews and Christians alike, not only includes the Book of Proverbs, but also explicitly introduces proverbs as a popular genre. Thus, in Genesis, popular wisdom opens, as well as concludes the story of the creation of woman: "It is not good that man should be alone" (Genesis 2:18) and: "Therefore a man shall leave his father and mother and be joined to his wife, and they shall become one flesh" (Genesis 1:24). ${ }^{24}$ Like in the story of woman's creation, proverbs also frame the story of Saul's crowning as king of Israel, that in fact exposes the process of proverb formation, visible in the variation from the first to the second application of the same proverb with very slight variation. The first proverb appears at the very beginning of Saul's appearance in the narrative:

And it happened, when all who knew him formerly saw that he indeed prophesied among the prophets, that the people said to one another, "What is this that has come upon the son of Kish? Is Saul also among the prophets?" Then a man from there answered and said, "But who is their father?" Therefore it became a proverb: "Is Saul also among the prophets?" (1 Sam 10:11-12).

The second instance shows that the proverb has been "orally canonized" as confirmed by usage: 25

And he also stripped off his clothes and prophesied before Samuel in like manner, and lay down naked all that day and all that night. Therefore they say, "Is Saul also among the prophets?" (1 Samuel 19:24)

Riddles too have an ancient lineage, as the following Sumerian didactic example shows:

A house based on a foundation like the skies / A house one has covered with a veil like a secret box / A house set on a base like a goose/One enters it blind,/Leaves it seeing,/Answer: the School. ${ }^{26}$

The riddle of the Sphinx was apparently so well known in Ancient Athens that Sophocles needed not to spell it out in his Oedipus Tyrannos, and we know it from a later source. ${ }^{27}$ The Hebrew Bible provides a context of performance, demonstrating the riddle's social power and efficacy: ${ }^{28}$

Then Samson said to them: "Let me pose a riddle to you. If you can correctly solve and explain it to me within the seven days of the feast, then I will give you thirty linen garments and thirty changes of clothing. But if you cannot explain it to me, then you shall give me thirty linen garments and thirty changes of clothing."

And they said to him: "Pose your riddle, that we may hear it"

So he said to them: "Out of the eater came something to eat, and out of the strong came something sweet."

Now for three days they could not explain the riddle.

But it came to pass on the seventh day that they said to Samson's wife: "Entice your husband, that he may explain the riddle to us, or else we will burn you and your father's house with fire. Have you invited us in order to take what is ours? Is that not so?"

23 Aristotle, Rhetoric. Translation from the Greek J.H. Freese. 1926. http:/ / www.perseus.tufts.edu/hopper / text?doc=Perseus\% 3Atext\%3A1999.01.0060\%3Abook\%3D1\%3Achapter\%3D1 (accessed on 19 September 2017).

24 (Hasan-Rokem 1990).

25 (Hasan-Rokem 2015).

26 (Civil 1987).

27 (Rokem 1996).

28 (Abrahams 1980; Pagis 1996, op. cit., pp. 81-108; Kaivola-Bregenhøj 1996, op. cit., pp. 10-36; Handelman 1996, op. cit., pp. 37-61). 
Then Samson's wife wept on him, and said: "You only hate me! You do not love me! You have posed a riddle to the sons of my people, but you have not explained it to me."

And he said to her: "Look, I have not explained it to my father or my mother; so should I explain it to you?" Now she had wept on him the seven days while their feast lasted. And it happened on the seventh day that he told her, because she pressed him so much. Then she explained the riddle to the sons of her people. So the men of the city said to him on the seventh day before the sun went down: "What is sweeter than honey? And what is stronger than a lion?"

And he said to them: "If you had not plowed with my heifer, You would not have solved my riddle!" (Judges 14:12) 29

\section{The Social Context of Ancient Folklore: Tools of Power and Subversion}

Ancient texts also retain a rich variety of folk narratives. In the Rabbinic literature of the Talmuds, the Palestinian Talmud or the Yerushalmi and the Babylonian Talmud or the Bavli, and the Midrash compilations, the preferred folk narrative genre is the legend with its demonstrable roots in the experienced and known reality. Among the legends of the Rabbis, those that describe the acts and events relating to individuals from their own elite milieu are abundant.

A good example of the way such legends construct authority and social order is the tale of the death of the imposing figure of Rabbi Judah Ha-Nasi, also known as the Prince. Rabbi Judah served as the political leader of the Jewish population in Roman Judea, and edited the constitutive text of most rabbinic literature, the Mishnah, at the beginning of the third century CE. Set in the tractate Ketubot ("marriage contracts") of the Bavli, the tale articulates hegemony and social gaps in multiple ways:

On the day when Rabbi died, the rabbis decreed a public fast and offered prayers for heavenly mercy. And they announced: Whoever says "Rabbi is dead" will be stabbed with a sword.

Rabbi's maidservant ascended the roof and said: "Those above claim Rabbi, and those below claim Rabbi; may it be the will that those below will overpower those above." Yet when she saw how often he restored to the privy, painfully taking off his tefillin [phylacteries] and putting them on again, she prayed: "May it be the will that those above will overpower those below." And the rabbis did not cease to pray for mercy.

She took a jar and threw it down from the roof to the ground. [Because of the noise] they were silent [from asking mercy], and Rabbi died (bKetubbot 104a). ${ }^{30}$

The tale displays a series of hierarchical relationships: between men and women, between Rabbi Judah as primus inter pares and the other rabbis, and not least between the human sphere below, and the divine sphere above. It also shows how those two spheres are functionally interconnected, as the prayer of the sages prolongs the life of Rabbi Judah, and the trick of the maidservant releases him from his suffering. The narrative becomes a strong statement about the tabooed theme of merciful death, almost in favor of euthanasia. The hierarchical system, at least for a moment, albeit in a crucial moment, collapses, as the maidservant undermines the effect of the prayer of the sages.

The presence of women who have a say, and a powerful say at that, is relatively rare in Rabbinic texts. Dina Stein concludes her chapter on the relationship between Rabbi Judah and his maidservant in a number of tales, as follows:

In the body of rabbinic discourse, Rabbi Judah's maidservant is an other within, and other who is recognized as being seated at the heart of its being. Insofar as discursive practices

29 (Camp and Fontaine 1990; Zacovitch 1988).

30 (Stein 2012). 
are the mechanisms through which a culture constructs its identity (and, by implication, it hegemony), this stranger within plants seeds of ambiguity. ${ }^{31}$

Stein shows how the tale both establishes Rabbinic authority and power, and points to its cracks that let other powers, such as the female voice here, act out their presence.

Dream interpretation is a privileged cultural practice in the Ancient Near East ${ }^{32}$ and in Greece. ${ }^{33}$ In Late Antiquity, it continued being a respected art of divination, as well as a means of diagnosing and healing disease. ${ }^{34}$ It is thus with good reason that Michel Foucault took the most famous book of ancient dream interpretation, Artemidorus' Onerirocritica, ${ }^{35}$ as his point of departure for the third volume of his History of Sexuality. ${ }^{36}$ We do not however share Foucault's tendency to see the dreams as reflections of social realities, overly underplaying the role of imagination in the production of dreams and the discourses on them. ${ }^{37}$ Rabbinic literature has produced a veritable "dream tractate" in the last chapter of tractate Berakhot ("blessings") of the Babylonian Talmud, that rather than listing patent interpretations for dreams, embeds them in narratives and interactive discourses. Similar texts of dream interpretation are also extant in other Rabbinic works, such as the one below: ${ }^{38}$

A woman once came to Rabbi Eleazar.

She said to him: "In my dream I saw the beam of the house breaking."

He said to her: "That woman [meaning the dreamer] will bear a male child." And so she did. She came at another time and did not find him [R. Eleazar] there, but found his students. She said to them: "Where is your Rabbi?"

They said to her: "What do you want?"

She said to them: "In my dream I saw the beam of the house breaking."

They said to her: "That woman will bury her husband."

When she left she heard that her husband was dead and she began to scream. R. Eleazar heard her voice and said to her: "What do you want?"

His students said to him: "She came and asked us about a dream."

Said he to them: "And what did you tell her?"

Said they: "We told her that that woman would bury her husband."

Said he: "You have lost a human being. Is it not written "And it came to pass, just as he interpreted to us, so it happened'? (Genesis 41:13 NKJV)

$$
\text { (Lamentations Rabbah 1, 1). }{ }^{39}
$$

The tale is embedded in the Rabbinic elaboration on the Biblical Book of Lamentations (ca. 6th century CE; however, the dating of Rabbinic literature is too complicated to introduce at length here). The tale demonstrates how dream interpretation is constructed in a discursive interaction, and how it is contingent on the life experience and the wisdom of the interpreter. The inexperienced students provide a rash and morbid interpretation, flatly interpreting breaking as death, thus leading to death, whereas the master's ripe experience of life produces life and birth, interpreting the beam as the body of the birth-giving woman, and labor as its temporary breaking.

This dream also serves to demonstrate the intertextuality of various folklore traditions of the ancient world. Thus, Penelope's rather famous dream in the Odyssey also figures the beam of her home and foresees her husband's return. ${ }^{40}$ The prominence of beams in dreams in this cultural sphere may

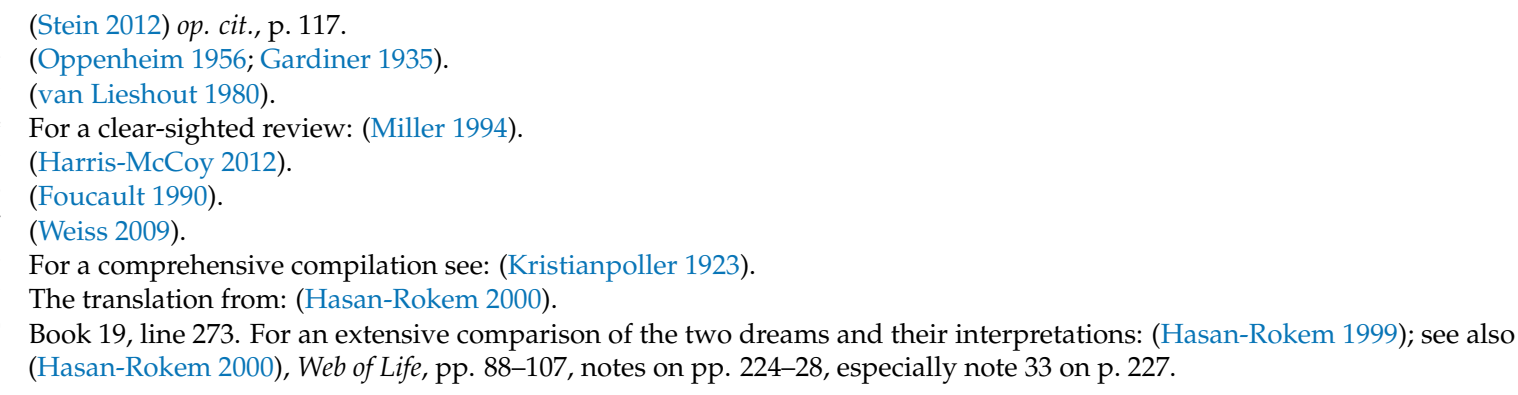




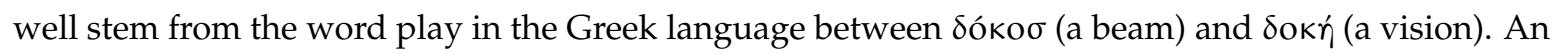

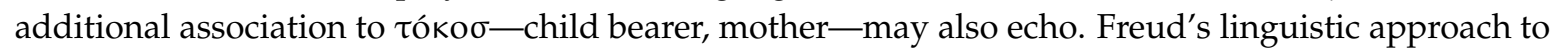
dream interpretation is thus rooted in a deep knowledge and intuition of cultural traditions. ${ }^{41}$

Dreams interpreted in Rabbinic literature are therefore closely linked to textual interpretation, and especially the interpretation of Scripture, which is the intellectual and epistemological basis of the rabbinic project in general. Dream interpretation is positioned in a juncture between textual practices and embodied practices, and it translated texts and visions into rituals, customs and even objects, such as amulets.

Finally, we shall mention one more genre of folklore that is pregnant with subversive power, namely laments. ${ }^{42}$ Almost universally viewed as a genre practiced by women, laments relate to existentially explosive and vital themes. They are set on the volatile bridge between life and death, marked above all by disconnection and total separation. Laments have been part of human expressive culture since earliest antiquity, found in ancient Mesopotamian and Egyptian texts, as well as in literary documents such as Homer's Iliad, the book of Lamentations, and other texts in the Hebrew Bible. They also often bear in the text itself the most palpable references to the performing body of the lamenters. That may be the reason that the study of laments, perhaps more than of any other genre, has stimulated the study of classical Greek sources illuminated by ethnographical, folkloristic, and anthropological research. The pioneering study of oral performance in the work of Margaret Alexious, ${ }^{43}$ and in particular in the feminist scholarship of Nicole Loraux (2002), ${ }^{44}$ much inspired by Jean-Pierre Vernant, ${ }^{45}$ are important examples. The biblical book of Lamentations was quickly recognized as part of the folk poetry of the ancient Israelites. Johann Gottfried Herder (1744-1803), a central figure of the German Enlightenment and Romanticism, and a forerunner of modern folklore studies, mentioned Lamentations in his elaborate essay "Vom Geist der hebräischen Poesie". 46 An early ethnographically informed work on Lamentations was Hedwig Jahnow's comparative study, based on earlier studies of Middle Eastern folk customs and oral literature collected mainly in Palestine by pioneering scholars in the field, such as Gustaf Dalman (1855-1941). ${ }^{47}$ Jahnow's (1879-1944, in Theresienstadt) comparative method echoed contemporary Central and North European folklore studies, and drew inspiration from Sir James Frazer's "Myth and Ritual" school.

As Nicole Loraux has demonstrated with regard to laments in classical Athens and Vered Madar among Yemeni Jews, ${ }^{48}$ lamenting is a strictly restrained and policed activity. Representatives of the male hegemonic order have, in these and many other cultures, instituted firm regulations about where, when, and for how long laments may be performed, and especially where and when they will not be tolerated ${ }^{49}$ Lamenting involves challenging the divine force or forces, and men cautiously seem to prefer not to take the risk, unless they are select, exceptional, indeed, almost marginal individuals, such as prophets, who frequently challenge God. As lamenters, women are thrown into a zone of risk somewhat akin to the situation of the Pythian oracle at Delphi, placed between the known and the unknown, and of the Woman of En-Dor, with her special talent to tread the borderlands between the

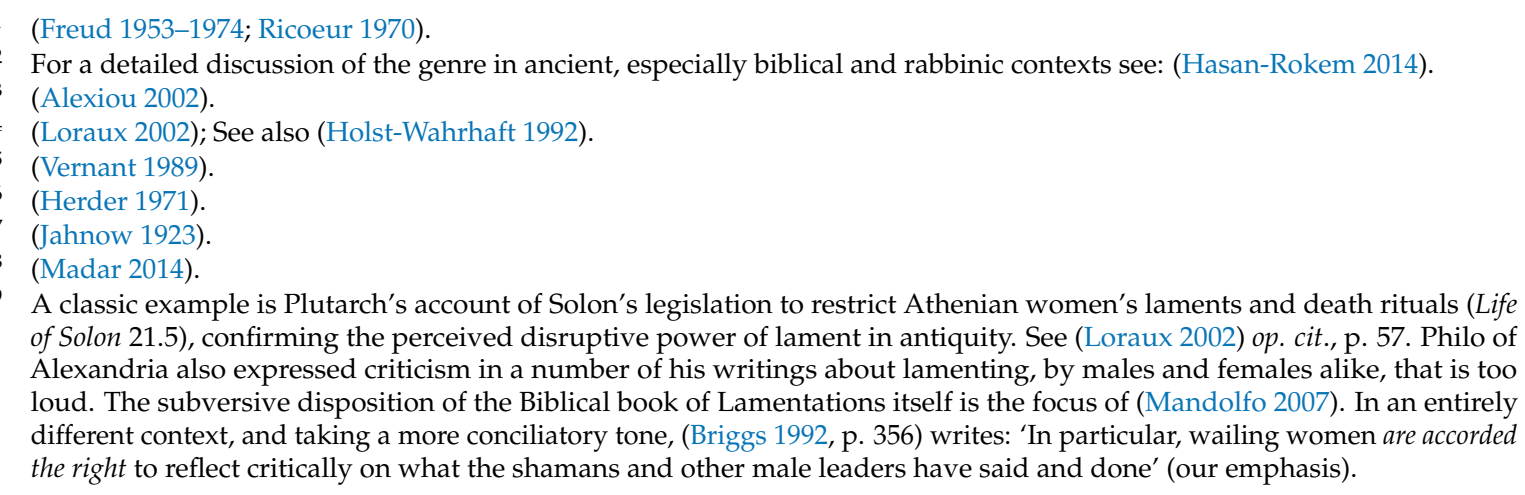

A classic example is Plutarch's account of Solon's legislation to restrict Athenian women's laments and death rituals (Life of Solon 21.5), confirming the perceived disruptive power of lament in antiquity. See (Loraux 2002) op. cit., p. 57. Philo of Alexandria also expressed criticism in a number of his writings about lamenting, by males and females alike, that is too loud. The subversive disposition of the Biblical book of Lamentations itself is the focus of (Mandolfo 2007). In an entirely different context, and taking a more conciliatory tone, (Briggs 1992, p. 356) writes: 'In particular, wailing women are accorded the right to reflect critically on what the shamans and other male leaders have said and done' (our emphasis). 
dead and the living, and to summon a dead spirit. ${ }^{50}$ The Book of Lamentations itself underlines from its opening lines the utter solitariness of the lamenting woman:

How lonely sits the city

That was full of people!

How like a widow is she,

Who was great among the nations!

The princess among the provinces

Has become a slave!

(Lamentations 1.1; NKJV)

The Book of Lamentations is part and parcel of a shared tradition of the Ancient Near East. At the heart of the ancient Babylonian city, laments were weeping gods and especially goddesses, who lamented their destroyed cities and temples. ${ }^{51}$ Texts found in the North Canaanite city of Ugarit on the coast of the Mediterranean also mention lamenting as a women's genre. ${ }^{52}$

Scholars of Ancient Near Eastern poetry and culture have emphasized the strong embeddedness of the laments in ritual and ceremonial contexts. ${ }^{53}$ The texts themselves bear witness to the performative aspects of the laments by referring to gestures, expressions and movements related to lamenting. ${ }^{54}$

Rabbinic literature has retained some texts of laments, such as the patriarchs' poetic lament mourning the terrible fate of their offspring being dragged to exile in Babylonia. This is the only poem of its kind in Lamentations Rabbah, mentioned above, using the spoken Aramaic idiom and, in what seems a natural rhetorical choice, focusing on the suffering bodies:

Woe that this has befallen our children,

how you were like fatherless orphans,

how you were struck by midday sun and summer heat without dress or cover;

how you were pushed in lines, stripped of shoes and without sandals;

how you were carrying heavy burdens;

how you were bound with your arms behind your backs;

how you could not swallow the saliva of your mouth. ${ }^{55}$

\section{Closing Words for an Incomplete Essay}

We knew even before we undertook the task that there would be no way to bring to the readers the indescribable abundance of the folklores of the Ancient world. Instead of making long inventories and providing summaries and reviews of works, we chose to present some of our favorite ancient folklore texts, trying to sketch an outline and to introduce some concrete examples. Hampered by the limits of time, space and our knowledge, we can only hope to serve the readers with an aperitif that will whet their appetites.

(Seremetakis 1991) emphasizes the connection between the practices of divination and lamenting in the longue durée of the Greek lamenting traditions up to modernity.

51 (Kramer 1983).

52 (Coogan and Smith 2012, pp. 30; 53; 73; 88; 126); on p. 90 "women's laments" is a generic term; however, the laments mentioned are from gods and persons of both sexes; on pp. 143-44 there is an actual lament text; (Smith and Pitard 2009), on Baal's lament in CAT 1.3 IV.

53 (Maul 2005; Olyan 2004).

54 (Hasan-Rokem 2014, pp. 42-47).

55 Lamentations Rabbah, proem 34, Solomon Buber's edition, Vilna 1899, pp. 27-28. Cf. (Sokoloff and Yahalom 1999) on laments pp. 27-33; Lamentations Rabbah is mentioned several times (pp. 27, 28, 30); laments for the destruction of the temple are also mentioned (p. 28) and there are other liturgical poems for 9th of Av, the day commemorating the destruction of both the First and the Second Temples. See also laments of women from the Babylonian Talmud, tractate Mo'ed Qatan f. 28b, presented in the Aramaic original and in English translation by Peter Cole in The Defiant Muse - Hebrew Feminist Poems from Antiquity to the Present, A Bilingual Anthology (Kaufman et al. 1999) 
We shall, however, demonstrate in this final section how texts identified by us as ancient folklore challenge the epistemological dimensions of our perception of the past.

In the Lives of the Emperors by Suetonius an anecdote on Tiberius is told in chapter 60:56

A few days after he reached Capreae and was by himself, a fisherman appeared unexpectedly and offered him a huge mullet; whereupon in his alarm that the man had clambered up to him from the back of the island over the rough and pathless rocks, he had the poor fellow's face scrubbed with the fish.

And because in the midst of his torture the man thanked his stars that he had not given the emperor an enormous crab that he had caught, Tiberius had his face torn with the crab also. ${ }^{57}$

Folk narrative scholars will recognize the motif J2563: “Thank God they weren't peaches!"58, well known in Southern Europe and among speakers of the Romance languages. Suetonius (69-122, or later, CE) was a Roman biographer-historian, well connected with rulers (e.g., Trajan, Hadrian), and intellectuals (e.g., Pliny). His writings have been trusted by generations of historians regarding mainly 1st century CE life and politics in Rome. In a somewhat less trusted, and about three centuries later work, the pseudonymously collectively authored Historia Augusta (Scriptores Historiae Augustae), which is one of the main sources for the life of Emperor Hadrian, there is the following tale about him:

He surpassed all kings by his gifts. Often he bathed in the public baths, even when everyone was present, as a result of which the following bathing joke became well-known: on one occasion he had seen a certain veteran, known to him in military service, rubbing his back and the rest of his body on the wall; he asked why he had the marble scrape him, and when he learned that this was done for the reason that he did not have a slave, he presented him both with slaves and with the cost of their maintenance. But on another day when several old men were rubbing themselves on the wall to arouse the emperor's generosity, he ordered them to be called out and to rub each other down in turn. ${ }^{59}$

In both tales, the narrator focuses on the power of the emperor with regard to his subjects. Whereas the unpopular Tiberius is described as erratically acting out of sudden fright, causing the poor well-meaning fisherman undue suffering, the much admired and-like many other emperors-posthumously deified Hadrian, is shown as a just and a smart judge of human nature, as well as a man of the people. Like so much else reported on Hadrian, this may have happened, ${ }^{60}$ but is also articulated in terms of a culturally specific genre, a "bathing joke" apt for Roman emperors known for building baths. Both cases substantiate Bowersock's claim; "For any coherent and persuasive interpretation of the Roman empire, it becomes obvious that fiction must be viewed as part of its history." ${ }^{\prime 1}$ For scholars of folklore, the texts map the genre of legend, bearing witness to the inevitable interaction between imagination and reality in the verbal articulation of the past, and defying the stark dichotomy between fact and fiction.

To further illuminate the potentials of legendary history, let us bring one more example from Rabbinic literature, which is discernably connected with the two historical legends quoted from Roman historical sources:

Hadrian, let his bones be milled, was walking up from Tiberias to the Land of Israel when he saw a man planting saplings.

(Tranquillus 1964) (Loeb Classical Library; orig.pub. 1913, based on Ihm's text) I: 376-77. This and the following examples are extensively and analytically discussed in: (Hasan-Rokem 2003).

57 (Hasan-Rokem 1990, op. cit., p. 116).

58 (Thompson 1955-1958). Multiple parallels from Latin, Italian, Arabic and Hebrew sources in: (Hasan-Rokem 2003, pp. 86-137).

59 (Birley 1976), the life of Hadrian, pp. 57-95; the Latin version that we used is in (Benario 1980; Hasan-Rokem 2003).

60 On conjecture in history writing with special reference to Hadrian (Birley 1997), see; (Hasan-Rokem 2003, op. cit., p. 125).

61 (Bowersock 1997). 
Said Hadrian: Old man, old man, up at sunrise free at sunset-had you toiled in your youth you would be free of toil in your old age.

Said the old man: By your life sir, I have toiled sunrise and sunset and what He wants He does.

Said Hadrian: By your life old man, if these saplings yield in your lifetime, let me taste them. The old man was fortunate and the saplings yielded in his lifetime. So he filled a basket with figs and went and stood in [Hadrian's] presence.

Said [the emperor]: Who are you?

And he replied: I am the old man whom you passed by and told, if these saplings yield in your lifetime let me taste them.

Said [the emperor]: Empty his basket and fill it with dinars.

That having been done to him he went home and told his family.

When the neighbor heard that, she went and said to her husband: Son of dark, son of dark, have you heard that this king loves figs?

Her husband asked her: How do you know?

She told: Our old neighbor filled his basket with figs, and it was filled with dinars.

So he got up before daybreak and filled his saddlebag and loaded the donkey and went and stood in the emperor's presence.

When he was asked "who are you" he told them: I have heard that this king loves figs.

[The emperor] told [his servants]: Go and make him stand at the gate of the palace and every one who happens to pass by throws [one of his fruits] in his face.

That having been done to him he went home and told his family.

They told him: Praise your Creator that they were figs rather than citrons, and that they were ripe rather than unripe. ${ }^{62}$

In classical folk narrative study terms, this tale exhibits a conglomeration between two international tale types: "Planting for the next generation" (AT 928), a wisdom novella on "clever acts and words", and "Thank God They Weren't Peaches" (AT 1689), a humorous tale on "the stupid man". ${ }^{63}$ It demonstrates the genre versatility of ancient folk narratives, combining the wisdom novella where the old man knows the right answers to persuade the emperor, the humorous tale, punishing the greedy neighbor with a characteristic anti-feminist flavor, a moral tale, praising the old man's selfless care for the next generation, and a historical legend about Hadrian. It also fits into the Scripture based framework of the Rabbinic texts, in its association with the lectionary from Leviticus 19:25 (NKJV): "When you come into the land, and have planted all kinds of trees for food, then you shall count their fruit as uncircumcised. Three years it shall be as uncircumcised to you. It shall not be eaten."

The multi-genre character of the text may account for the multiple levels of interpretation that it produces. There is moral retribution to the virtuous old man, and the order on earth where the emperor rewards and punishes parallels the cosmic order where the Creator rules, and where trees and fruits grow and ripen in due time. On this level the tale seems to accede to the existing hierarchy, including the Roman rule in Judea and the Galilee, following the policy of Rabbi Judah ha-Nasi, mentioned above. Notably the only sign of animosity against Hadrian, who is in most Rabbinic historical accounts portrayed as a cruel and arbitrary tyrant, is in this tale the formulaic curse attached to his name: "may his bones be milled". However, another interpretive possibility looms: the stereotypically "evil neighbor woman" known from Hellenistic dramas of Menander and from folk literature, carries here as elsewhere the female voice of subversion against authority. She plans the reversal of the imperial taxation that was especially heavy under Hadrian, according to Talmudic sources. Her pelted

62 Leviticus Rabbah 25.5 (Munich MS). (Margulies 1972; Hasan-Rokem 2003, op. cit., p. 87).

63 (Aarne and Thompson 1961) [3rd printing 1987], AT 928 at p. 325 and AT 1689 at pp. 474-86. Cf. Hans-Jörg Uther's revised version of the same, FFC volume 284, 2004, p. 567 erroneously refers to a Talmudic version of type 928 from the 1st century CE; volume 285 2005, pp. 376-77 does not mention versions of AT 1689 in Rabbinic literature. 
husband emerges as nothing less than a local hero, a suffering hero. She does not succeed but the tale communicates the inherent value of resistance against evil domination.

Ending our brief journey through ancient folklore will hopefully leave the reader with a taste for more. There are so many texts that we could not introduce in this short piece: the Golden Ass by Apuleius, the legends and anecdotes included by historians Josephus, Suetonius, Dio Cassius, and others, the ethnographer Epiphanius' "Medicine Box", Panarion, the traveling historian Pausanias' Description of Greece. We could have introduced the epithalamia of the Song of Songs, the riddle tales of Lamentations Rabbah, the epic creation myths of ancient Babylonia, the foundation legends of the patriarchs and the tribes of Genesis, early Christian apocryphal saint's legends, and much more. Reflections on folklore too may be interesting for readers, such as Lucian's True Story, being a satire on folklore. We could also have shown some of the numerous mythical, legendary, quotidian, and imaginary illustrations carved in stone, arranged in mosaics, painted on stucco, drawn on parchment, etc.

Approaching ancient texts through the lens of folklore often enables us to hear the multiple voices encoded in them, and the many ideological and religious imaginations that have produced them. ${ }^{64}$

Author Contributions: This article was written in complete cooperation between the two authors.

Conflicts of Interest: The authors declare no conflict of interest.

\section{References}

Aarne, Antti, and Stith Thompson. 1961. The Types of the Folktale: A Classification and Bibliography. Folklore Fellows Communications. No. 182. Helsinki: Academia Scientiarum Fennica.

Abrahams, Roger. 1980. Between the Living and the Dead: Riddles Which Tell Stories. Folklore Fellows Communications. No. 225. Helsinki: Academia Scientiarum Fennica.

Alexiou, Margaret. 2002. The Ritual Lament in Greek Tradition. Cambridge: Cambridge University Press.

Baumann, Richard, and Charles L. Briggs. 2001. Voices of Modernity: Language Ideologies and the Politics of Inequality. Cambridge: Cambridge University Press.

Ben-Amos, Dan. 1967. Narrative Forms in the Haggadah: Structural Analysis. Unpublished dissertation, Indiana University, Bloomington, IN, USA.

Ben-Amos, Dan. 1971. Toward a Definition of Folklore in Context. JAF 84: 3-15. [CrossRef]

Benario, Herbert W. 1980. A Commentary on the "Vita Hadriani" in the "Historia Augusta". American Philological Association American Classical Studies 7; Missoula: Scholars Press.

Bendix, Regina F., and Galit Hasan-Rokem, eds. 2014. Introduction. In A Companion to Folklore, paperback ed. Hoboken: Wiley and Blackwell, pp. 1-5, 9-11. First published 2012.

Berdichevsky, Micah Joseph. 1990. Mimekor Yisrael; Classical Jewish Folktales. Collected by Micha Joseph Bin Gorion; Edited by Emanuel Bin Gorion and Dan Ben-Amos. Translated by I. M. Lask. 3 vols. Bloomington: Indiana University Press.

Birley, Anthony, ed. 1976. Lives of the Later Caesars. The First Part of the Augustan History with Newly Compiled Lives of Nerva and Trajan. Harmondsworth: Penguin books.

Birley, Anthony. 1997. Hadrian, the Restless Emperor. London: Routledge.

Bowersock, Glen W. 1997. Fiction as History: From Nero to Julian. Sather Classical Lectures 58; Berkeley: University of California Press, p. 12. First published 1994.

Briggs, Charles L. 1992. 'Since I Am a Woman, I Will Chastise My Relatives': Gender, Reported Speech, and the (Re)Production of Social Relations in Warao Ritual Wailing. American Ethnologist 19: 337-61. [CrossRef]

Buxton, Richard. 1994. Imaginary Greece, the Contexts of Mythology. Cambridge: Cambridge University Press, chp. 2.

64 There are many more sources for acquainting oneself with ancient folklore. E.g., (Hansen 2017; Ginzberg 1909-1938) and a number of later editions; See also: (Hasan-Rokem and Gruenwald 2014; Berdichevsky 1990). 
Camp, Claudia V., and Carol Fontaine. 1990. The Words of the Wise and Their Riddles. In Text and Tradition. Edited by Susan Niditch. Atlanta: Scholars Press, pp. 127-51.

Civil, Miguel. 1987. Sumerian Riddles: A Corpus. Aula Orientalia 5: 17-37.

Coogan, Michael D., and Mark S. Smith. 2012. Stories from Ancient Canaan, 2nd ed. Louisville: John Knox Press.

Dundes, Alan. 1965. The Study of Folklore in Literature and Culture: Identification and Interpretation. JAF 78: 136-42. [CrossRef]

Fine, Elizabeth C. 1984. The Folklore Text: From Performance to Print. Bloomington: Indiana University Press.

Foucault, Michel. 1990. The History of Sexuality, Vol. 3: The Care of the Self. Translated by Robert Hurley. New York: Vision Books. First published 1978.

Freud, Sigmund. 1953-1974. The Standard Edition of the Complete Psychological Works. Translated by German under the General Editorship of James Strachey, Anna Freud, Carrie Lee Rothgeb, and Angela Richards. London: Hogarth Press, vols. 4 and 5.

Gardiner, Alan. 1935. Heratic Papyri in the British Museum, Third Series, Chester Beatty Gift. London: Oxford University Press, pp. 7-27.

Ginzberg, Louis. 1909-1938. Legends of the Jews. Translated by Henrietta Szold, and Paul Radin. Index by Boaz Cohen; Philadelphia: Jewish Publication Society.

Graves, Robert, and Raphael Patai. 1983. The Hebrew Myth: The Book of Genesis. New York: Greenwich House.

Grimm, Brüder. 1815. Preface III-XII. In Kinder-und Hausmärchen. Berlin: Realschulbuchhandlung, vol. II.

Handelman, Don. 1996. Traps of Trans-formation: Theoretical Convergences between Riddle and Ritual. In Untying the Knot: On Riddles and Other Enigmatic Modes. Edited by Galit Hasan-Rokem and David Shulman. New York: Oxford University Press, pp. 37-61.

Hansen, William, ed. 2017. The Book of Greek and Roman Folktales, Legends, and Myths. Princeton: Princeton University Press.

Harris-McCoy, Daniel E. 2012. Artemidorus' Oneirocritica: Text, Translation, and Commentary. Oxford: Oxford University Press.

Hartog, François. 2001. Le Miroir d'Hérodote. Essai sur la représentation de l'autre. Paris: Gallimard. First published 1980.

Hartog, François. 2009. The Mirror of Herodotus: The Representation of the Other in the Writing of History. Translated by Janet Lloyd. Berkeley: University of California Press.

Hasan-Rokem, Galit. 1990. And God Created the Proverb... Inter-generic and Inter-textual Aspects of Biblical Paremiology or the longest way to the Shortest Text. In Text and Tradition-The Hebrew Bible and Folklore. Edited by Susan Niditch. Atlanta: Society of Biblical Literature Semeia Studies, pp. 107-19.

Hasan-Rokem, Galit. 1999. Communication with the Dead in Jewish Dream Culture. In Dream Cultures: Towards a Comparative History of Dreaming. Edited by David Shulman and Guy Stroumsa. New York: Oxford University Press, pp. 213-32.

Hasan-Rokem, Galit. 2000. The Web of Life: Folklore and Midrash in Rabbinic Literature. Translated by Batya Stein. Stanford: Stanford University Press, p. 104.

Hasan-Rokem, Galit. 2003. Tales of the Neighborhood: Jewish Narrative Dialogues in Late Antiquity. Berkeley: University of California Press, pp. 86-137.

Hasan-Rokem, Galit. 2009. Did the Rabbis Recognize the Category of Folk Narrative? European Journal of Jewish Studies 3: 19-55. [CrossRef]

Hasan-Rokem, Galit. 2014. Bodies Performing in Ruins: The Lamenting Mother in Ancient Hebrew Texts. In Laments in Jewish Thought: Philosophical, Theological, and Literary Perspectives. Edited by Ilit Farber and Paula Schwebel. Berlin: De Gruyter, pp. 33-63.

Hasan-Rokem, Galit. 2015. Negotiating Canons: Rabbinic Proverbs between Oral Tradition and Scripture. In Bis dat, qui cito dat: Gegengabe in Paremiology, Folklore, Language, and Literature Honoring Wolfgang Mieder on His Seventieth Birthday. Edited by Christian Grandl, Kevin J. McKenna, Elisabeth Piirainen and Andreas Nolte. Frankfurt am Main: Peter Lang Editions, pp. 163-79.

Hasan-Rokem, Galit, and Ithamar Gruenwald. 2014. Louis Ginzberg's Legends of the Jews: Ancient Jewish Folk Literature Reconsidered. Detroit: Wayne State University Press.

Herder, Johann Gottfried. 1971. The Spirit of Hebrew Poetry. Translated by John Marsh. Napersville: Aleph \& Press. First published 1833.

Holst-Wahrhaft, Gail. 1992. Dangerous Voices: Women's Laments and Greek Literatur. London: Routledge. 
Jahnow, Hedwig. 1923. Das hebräische Leichenlied im Rahmen der Völkerdichtung (The Hebrew Dirge in the Framework of Folk Poetry). Beihefte zur Zeitschrift für die alttestamentliche Wissenschaft 36; Giessen: A. Töpelmann.

Kaivola-Bregenhøj, Annikki. 1996. Riddles and Their use. In Untying the Knot: On Riddles and Other Enigmatic Modes. Edited by Galit Hasan-Rokem and David Shulman. New York: Oxford University Press, pp. 10-36.

Kaufman, Shirley, Galit Hasan-Rokem, and Tamar Hess. 1999. The Defiant Muse-Hebrew Feminist Poems from Antiquity to the Present, A Bilingual Anthology. New York: The Feminist Press at the City University of New York, pp. 61-62.

Kramer, Samuel Noah. 1983. The Weeping Goddess: Sumerian Prototypes of the Mater Dolorosa. The Biblical Archaeologist 46: 69-80. [CrossRef]

Kramer, Samuel Noah. 1988. History Begins in Sumer, 3rd ed. Philadelphia: University of Pennsylvania Press, chp. 16.

Kristianpoller, Alexander. 1923. Traum und Traumdeutung. Monumenta Talmudica. Wien: Benjamin Harz, vol. 4.

Krohn, Kaarle. 1926. Die folkloristische Arbeitsmethode (The Folklorist Work Method). Translated by Roger Welsch. 1971. As Folklore Methodology; Austin: University of Texas Press.

Loraux, Nicole. 2002. The Mourning Voice: An Essay on Greek Tragedy. Translated by Elizabeth Trapnell Rawlings. Ithaca: Cornell University Press.

Madar, Vered. 2014. Women's oral laments: Corpus and text-the body in the text. In Laments in Jewish Thought: Philosophical, Theological, and Literary Perspectives. Edited by Ilit Farber and Paula Schwebel. Berlin: De Gruyter, pp. 65-86.

Mandolfo, Carleen R. 2007. Daughter Zion Talks Back to the Prophets: A Dialogic Theology of the Book of Lamentation. Atlanta: Society of Biblical Literature.

Margulies, Mordecai. 1972. Midrash Wayikra Rabbah: A Critical Edition Based on Manuscripts and Genizah Fragments and Variants and Notes. Jerusalem: Wahrmann Books, pp. 576-79.

Maul, Stefan. 2005. 'Altorientalische Trauerriten', Der Abschied von den Toten. Trauerrituale im Kulturvergleich. Edited by Jan Assmann, Franz Maciejewski and Axel Michaels. Göttingen: Wallstein, pp. 359-72. Available online: http://archiv.ub.uni-heidelberg.de/propylaeumdok/996/1/Maul_AltorientalischeTrauerriten_2005. pdf (accessed on 1 March 2018).

Miller, Patricia Cox. 1994. Dreams in Late Antiquity: Studies in the Imagination of a Culture. Princeton: Princeton University Press.

Olyan, Saul M. 2004. Biblical Mourning: Ritual and Social Dimensions. New York: Oxford University Press.

Oppenheim, A. Leo. 1956. The Interpretation of Dreams in the Ancient Near East, with a translation of an Assyrian dream book. Transactions of the American Philosophical Society 46: 179-373. [CrossRef]

Pagis, Dan. 1996. Towards a Theory of the Literary Riddle. In Untying the Knot: On Riddles and Other Enigmatic Modes. Edited by Galit Hasan-Rokem and David Shulman. New York: Oxford University Press, pp. 81-108.

Patai, Raphael, Francis Lee Utley, and Dov Noy. 1973. Studies in Biblical and Jewish Folklore. New York: Haskell House Publishers.

Ranelagh, Elaine L. 1979. The Past We Share-The Near Eastern Ancestry of Western Folk Literature. London: Quartet Books, New York: Horizon Press.

Ricoeur, Paul. 1970. Freud and Philosophy: An Essay on Interpretation. Translated by Denis Savage. New Haven: Yale University Press, pp. 87-114.

Ricoeur, Paul. 1974. Listening to the Parables of Jesus. Criterion 13: 18-22.

Rokem, Freddie. 1996. One Voice and Many Legs: Oedipus and the Riddle of the Sphinx. In Untying the Knot: On Riddles and Other Enigmatic Modes. Edited by Galit Hasan-Rokem and David Shulman. New York: Oxford University Press, pp. 255-70.

Schwarzbaum, Haim. 1964. Talmudic-Midrashic Affinities of Some Aesopic Fables. Paper presented at 4th Congress of the International Society for Folk Narrative Research, Athens, Greece, September 1-9; pp. 466-83.

Seremetakis, Nadia. 1991. The Last Word: Women, Death, and Divination in Inner Mani. Chicago: University of Chicago Press.

Simon Shoshan, Moshe. 2012. Stories of the Law: Narrative Discourse and the Construction of Authority in Mishnah. New York: Oxford University Press.

Smith, Mark S., and Wayne T. Pitard. 2009. The Ugaritic Baal Cycle vol. II, Introduction with Text, Translation and Commentary of KTU/CAT 1.3-1.4. Supplement to Vetus Testamentum 114; Leiden: Brill, pp. 305-13. 
Sokoloff, Michael, and Joseph Yahalom. 1999. Shirat Beney Ma'arava: Aramaic Poems of the Jews of Palestine in the Byzantine Period. Jerusalem: The Israel Academy of Science. (In Hebrew)

Stein, Dina. 2009. Let the "People" Go?: The "Folk" and their "Lore" as Tropes in the Reconstruction of Rabbinic Culture. Prooftexts 29: 206-41. [CrossRef]

Stein, Dina. 2012. Textual Mirrors: Reflexivity, Midrash and the Rabbinic Self. Philadelphia: University of Pennsylvania Press, pp. 112-13.

Stern, David. 1991. Parables in Midrash: Narrative and Exegesis in Rabbinic Literature. Cambridge: Harvard University Press, pp. 6-7.

Sussmann, Yaakov. 2005. The Oral Learning-Literally: The Power of the Smallest Detail. Talmudic Studies 3: 209-384. (In Hebrew)

Thompson, Stith. 1955-1958. Motif Index of Folk Literature: A Classification of Narrative Elements in Folktales, Ballads, Myths, Fables, Mediaeval Romances, Exempla, Fabliaux, Jest-Books, and Local Legends, Rev. and enl. ed. Bloomington: Indiana University Press.

Tranquillus, C. Suetonius. 1964. Suetonius. With an English translation by J. C. Rolfe; London: William Heinemann, Cambridge: Harvard University Press.

Utley, Francis. 1965. Folk Literature: An Operational Definition. In The Study of Folklore. Edited by Alan Dundes. Englewood Cliffs: Prentice-Hall, pp. 7-24.

van Lieshout, R. G. A. 1980. Greeks on Dreams. Utrecht: HES Publications.

Vernant, Jean-Pierre. 1989. L'individu, la mort, l'amour: Soi-même et l'autre en Grèce ancienne. Paris: Gallimard.

Veyne, Paul. 1988. Did the Greeks Believe in Their Myths? An Essay on the Constitutive Imagination. Chicago: University of Chicago Press, pp. 42-44.

Weiss, Haim. 2009. 'I saw Pigeons keep on Coming to my Bed': Women in Ancient Jewish Dream Literature. El Presente 3: 157-68.

Winterbottom, M. 1970. Oxford Classical Texts. Oxford: Clarendon.

Yassif, Eli. 1999. The Hebrew Folktale: History, Genre, Meaning. Bloomington: IUP, pp. 72-79.

Zacovitch, Yair. 1988. The Life of Samson: A Critical-Literary Analysis (Judges 13-16). Jerusalem: Magnes Press. (In Hebrew)

Ziolkowski, Jan M. 2009. Fairy Tales from Before Fairy Tales: The Medieval Latin Past of Wonderful Lies. Ann Arbor: The University of Michigan Press.

(C) 2018 by the authors. Licensee MDPI, Basel, Switzerland. This article is an open access article distributed under the terms and conditions of the Creative Commons Attribution (CC BY) license (http://creativecommons.org/licenses/by/4.0/). 